\title{
Diagnostic accuracy of respiratory diseases in primary health units
}

\author{
Bruno Piassi de São José ${ }^{1 *}$, Paulo Augusto Moreira Camargos ${ }^{2}$, Álvaro Augusto Souza da Cruz Filho ${ }^{3}$, Ricardo de Amorim Corrếa ${ }^{4}$ \\ ${ }^{1}$ Master and Doctoral student of medicine - Postgraduate degree in Infectology and Tropical Medicine, Federal University of Minas Gerais Medical School - Physician at the Hospital das Clínicas -UFMG Pneumology \\ Outpatient Clinic, Belo Horizonte, MG, Brazil \\ ${ }^{2}$ Visiting Professor at the Pediatric Department - UFMG Medical School, Belo Horizonte, MG, Brazil \\ 3ProAr - Center for Excellence in Asthma, Federal University of Bahia, Salvador, BA, Brazil \\ ${ }^{4}$ Adjunct Professor IV- UFMG Medical School, Belo Horizonte, MG, Brazil
}

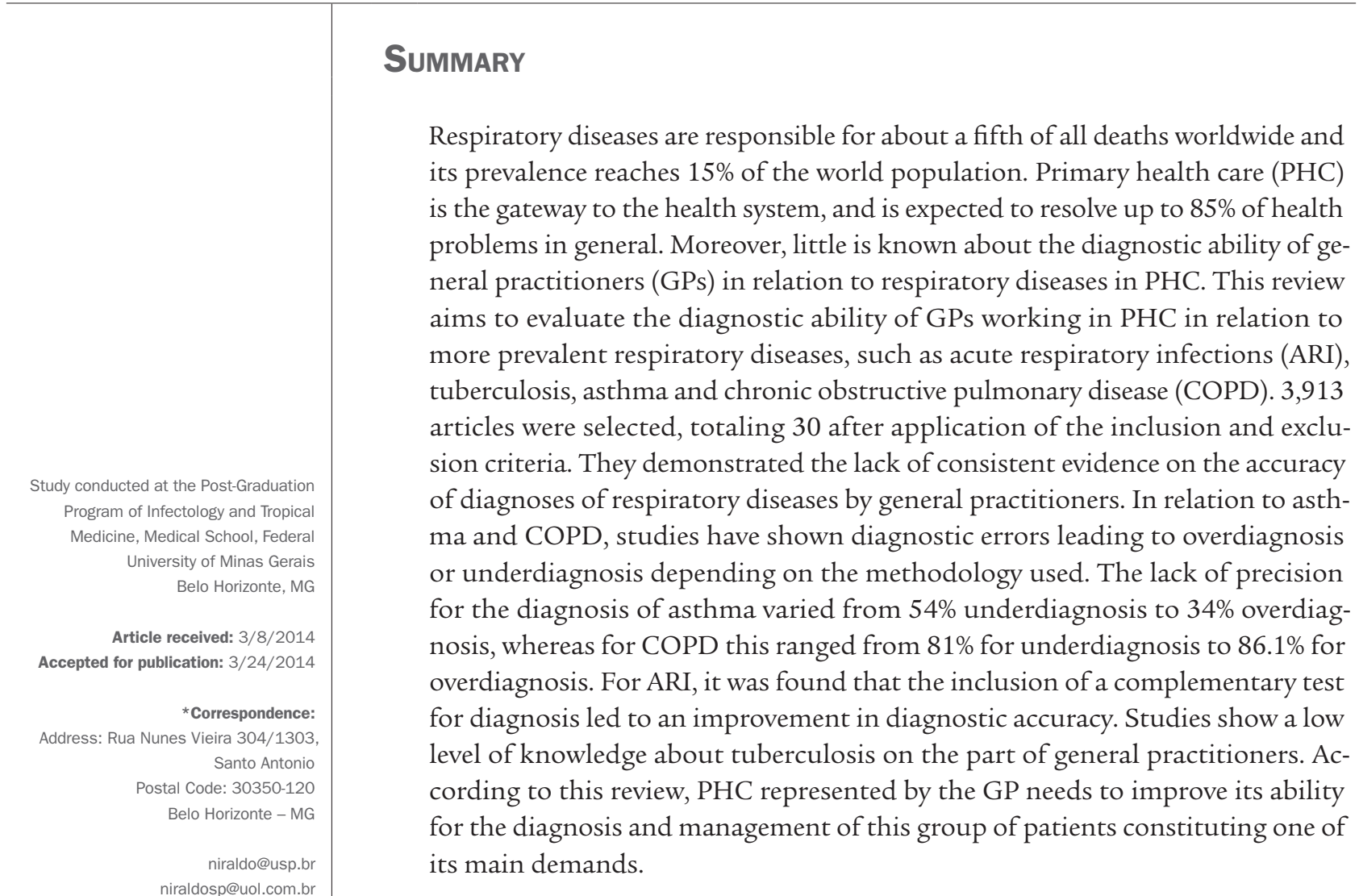

Keywords: respiratory tract diseases, primary health care, diagnosis, general practitioners, review.

\section{INTRODUCTION}

According to the World Health Organization (WHO), 20\% of the 59 million annual deaths by all causes are due to respiratory tract diseases. ${ }^{1,2}$ Among these, acute respiratory infections (ARI) occupy third place (3.6 million deaths; $6.1 \%$ of the total), while chronic obstructive pulmonary disease (COPD) occupies fourth place, with 3.28 million deaths (5.8\% of the total), and will reach third place by 2030 according to projections. ${ }^{3-5}$

More than a billion people worldwide - 15\% of the global population - suffer from some kind of chronic res- piratory disease, with half affected by one of the two most prevalent conditions: asthma $(235 \text { million })^{6}$ or COPD (210 million). ${ }^{7}$ Owing to this, around a third of appointments at primary health care (PHC) units worldwide are due to respiratory diseases. ${ }^{1}$

Among the difficulties encountered in PHC in relation to this group of diseases, we can mention imprecision in the diagnosis of asthma and COPD ${ }^{8-10}$ and excessive prescription of antibiotics for the treatment of acute respiratory diseases. ${ }^{111,12}$ In general, little is known about 
diagnostic ability and the elaboration of treatment plans for these conditions by PHC physicians, as well as the factors influencing them.

This article presents a review of the literature with respect to the diagnostic accuracy of general physicians in PHC in relation to the most prevalent respiratory diseases and those of greatest interest for public health, including ARI, tuberculosis, asthma and COPD.

\section{Methods}

A search of the literature was undertaken for articles assessing the concordance between the diagnosis by PHC physicians and specialists in respiratory diseases for the main respiratory illnesses in PHC services. The review also included studies using supplementary reference exams (spirometry) for asthma and COPD; acid-fast bacilli (AFB) tests for tuberculosis and C-reactive protein (CRP) and procalcitonin for ARI or for making clinical decisions, such as prescribing antibiotics.
The literature review was conducted using the PUBMED database covering the period from 1/1/1992 to $8 / 1 / 2012$, limited to studies conducted on humans and published in Portuguese, English and Spanish.

In the selection, cross-referencing was performed using these groups of MeSH keywords with free terms (FT) of relevance to the research: "diagnosis" (MeSH), "underdiagnosis" (TL) e "diagnostic concordance" (TL) com "respiratory tract infections" (MeSH), "asthma” (MeSH), "COPD” (MeSH) and "tuberculosis" (MeSH) with "primary health care" (MeSH) and "general practitioners" (MeSH; Figure 1).

As a result of the lack of studies about this issue in the literature, differences in methodology or the definitions of conditions were not used as exclusion criteria, as will be discussed below.

The diseases included in this review were ARI, asthma, COPD and tuberculosis. Articles that included other diseases such as sleep apnea, lung cancer and other respiratory diseases were excluded.

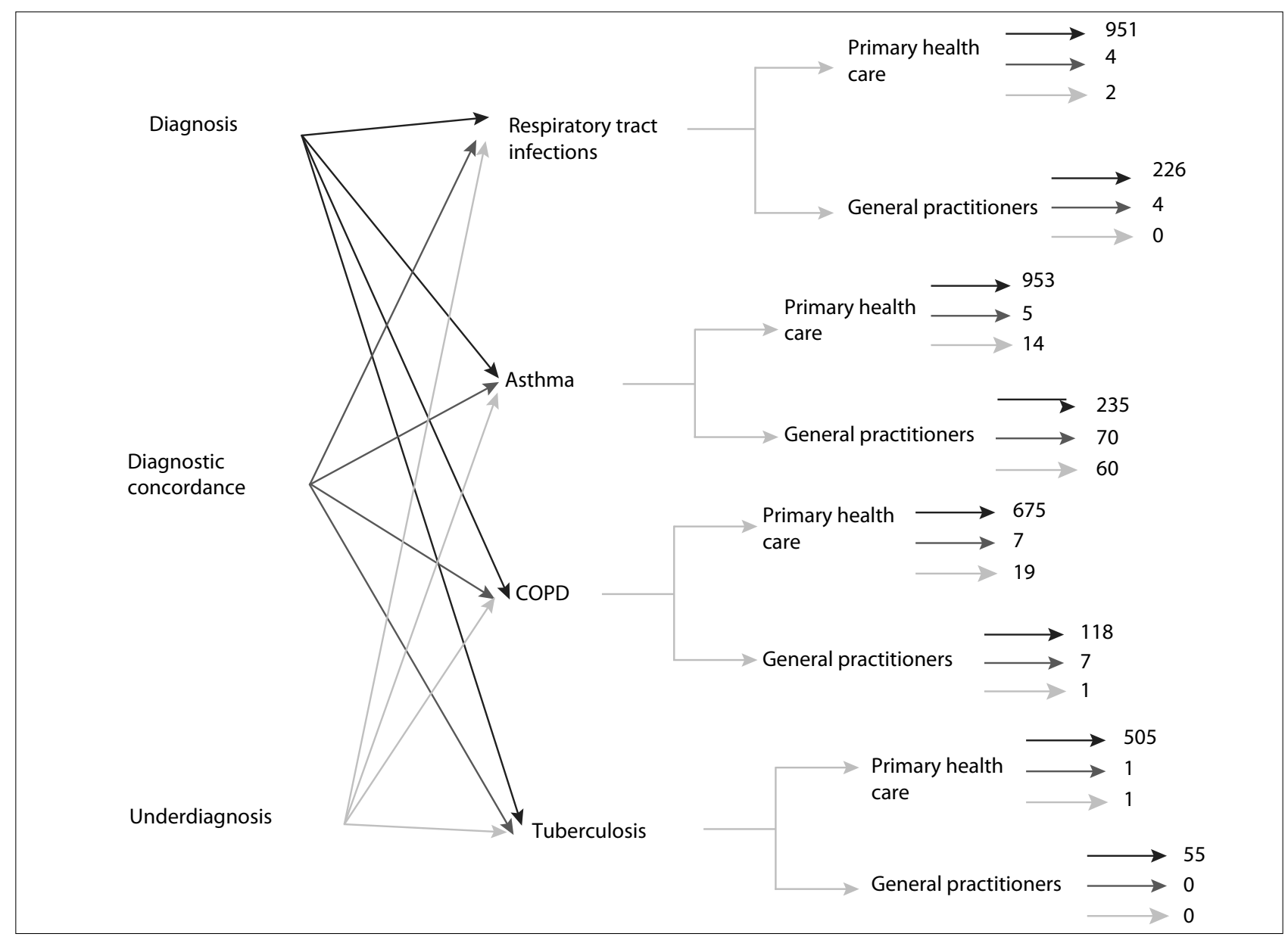

FIGURE 1 System for searching articles according to the keywords and number of articles found in each cross-reference. 


\section{RESULTS}

Thirty of the 3,913 articles encountered were selected according to the following flowchart (Figure 2).

Articles assessing the diseases of interest were not found in this set. The methodological heterogeneity encountered did not meet the criteria for conducting a meta-analysis. The results will be presented organized as follows: acute respiratory infections, tuberculosis, asthma, COPD, and asthma and COPD in conjunction.

Acute respiratory infections - ARI Upper respiratory tract infections

Among studies of upper respiratory tract infections (URTI), two used C-reactive protein (CRP) or used it as diagnostic aid, or as a reference method for assessment of diagnostic accuracy.

A single study verified the accuracy of the upper respiratory tract disease diagnosis. The authors evaluated the accuracy of the clinical diagnosis of pharyngitis using CRP dosage and leukocyte count in the two phases of the study. ${ }^{13}$ Another study also used the CRP as an auxiliary tool in the diagnosis of acute bacterial rhinosinusitis and prescription of antibiotics. ${ }^{14}$

Only one study assessed the concordance between general practitioners and specialists (pediatricians and ENT specialists) through a standardized questionnaire in the management of children with recurrent tonsillitis. There was disagreement between the signs and symptoms evaluated by the ENT specialists and general practitioners in the diagnosis of tonsillitis, pharyngitis or upper respiratory tract infection. ${ }^{15}$

\section{Lower respiratory tract infections}

Studies assessing the concordance or comparing the diagnosis and conduct of general physicians and specialists for lower respiratory tract infections were not encountered. The few studies encountered compared the diagnosis by general practitioners with a reference exam and are grouped in Table $1 .{ }^{11}$

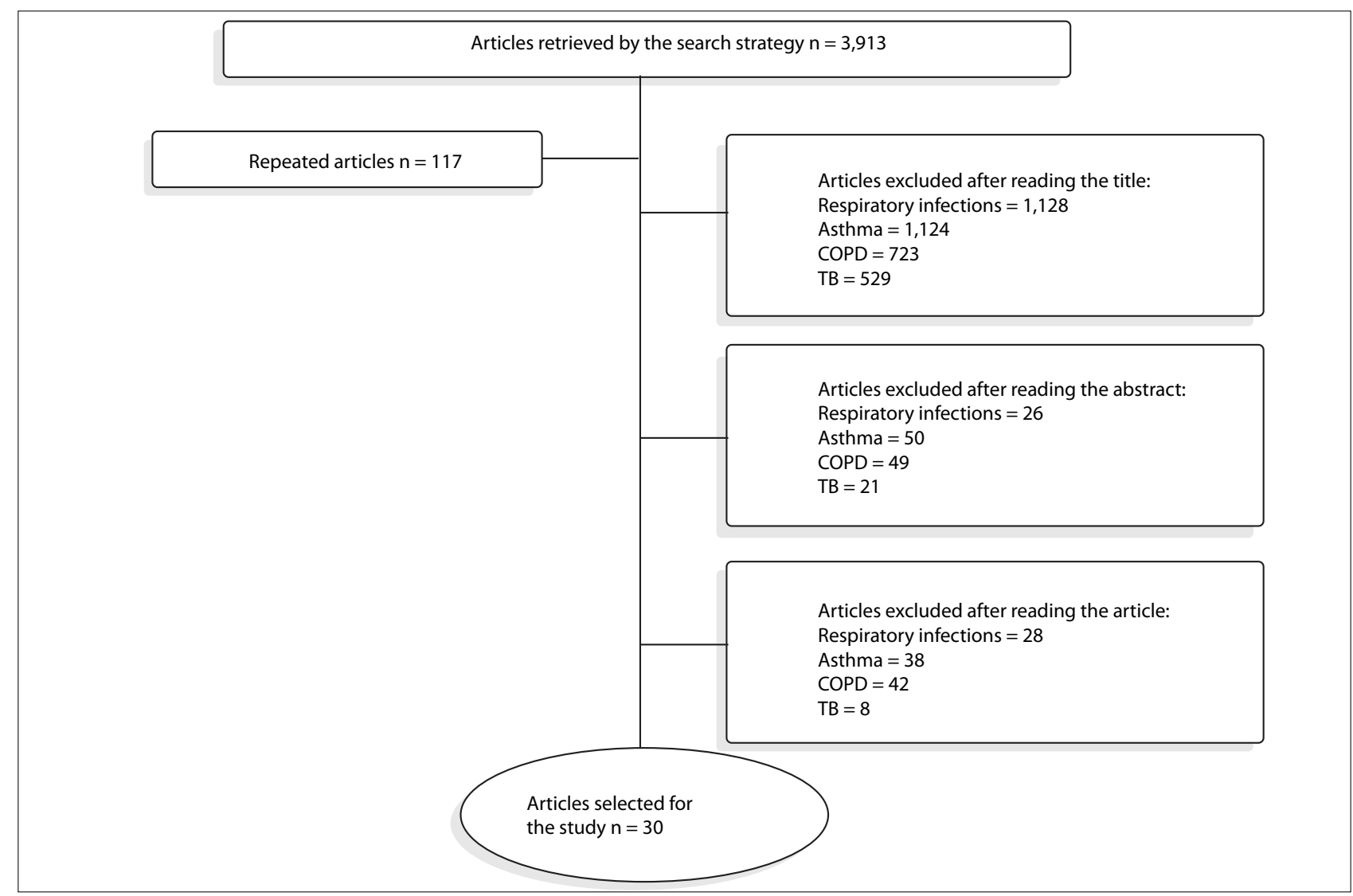

FIGURE 2 Flowchart for selection of articles according to the criteria adopted in the review. 


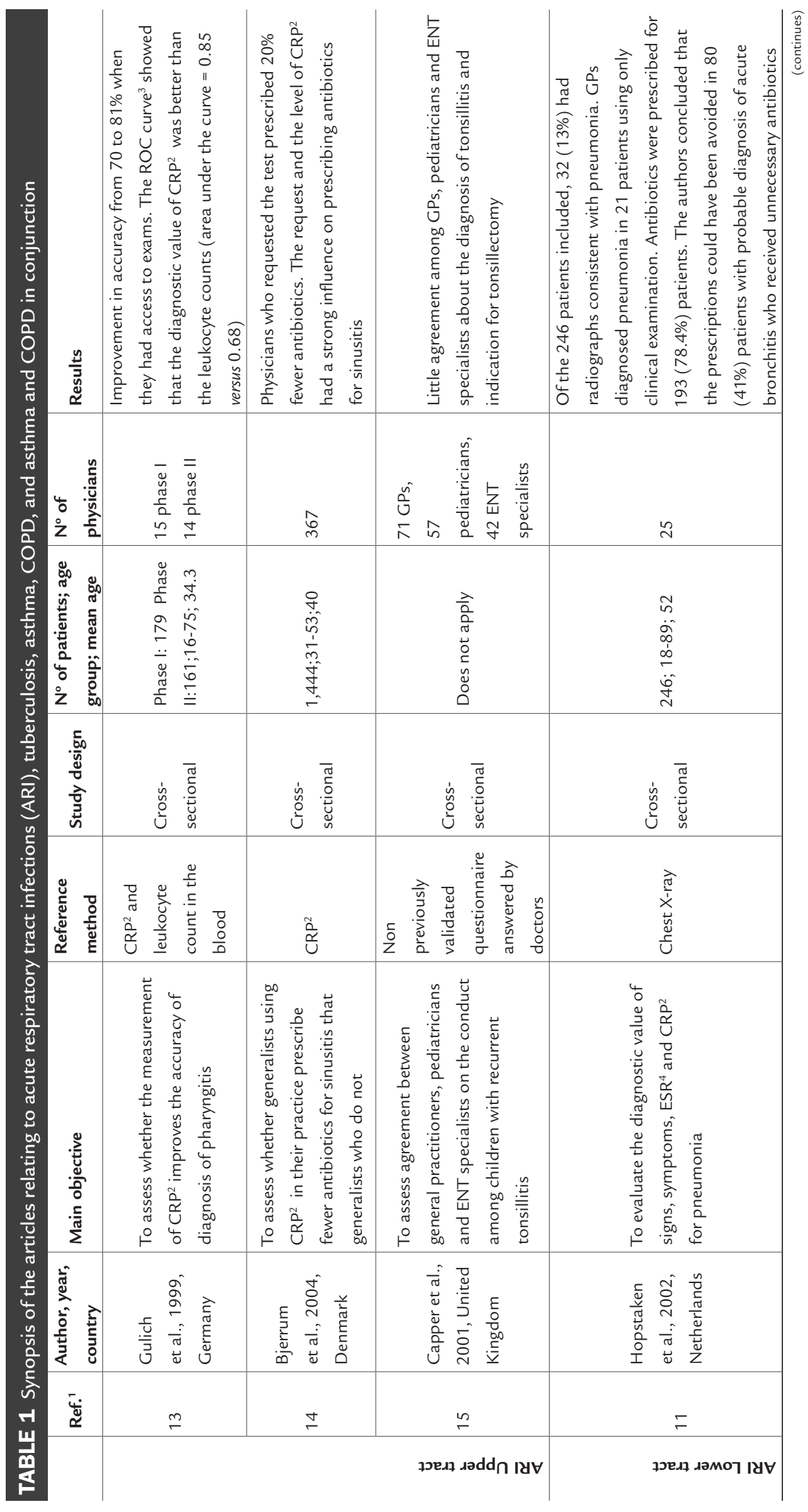




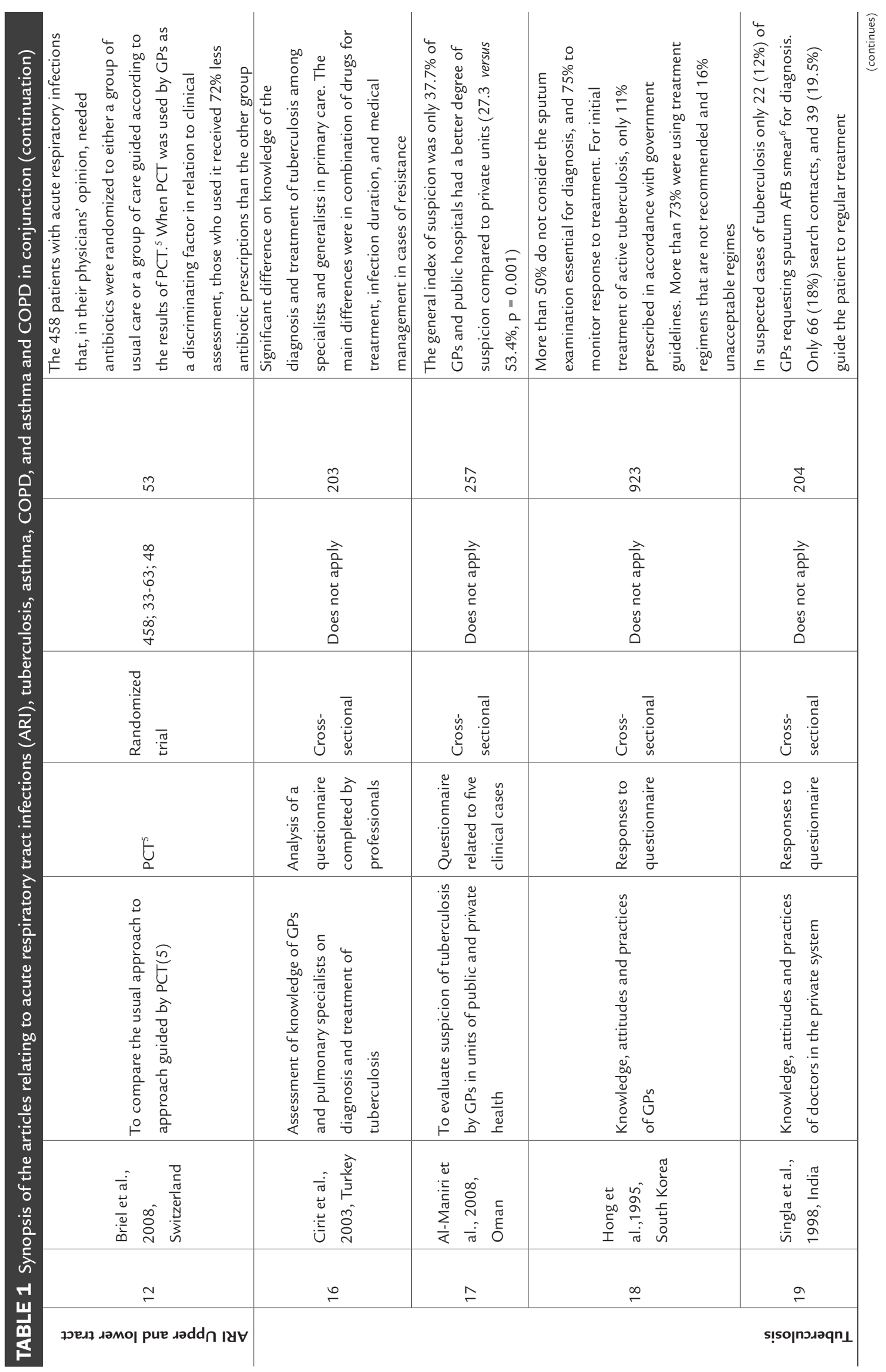




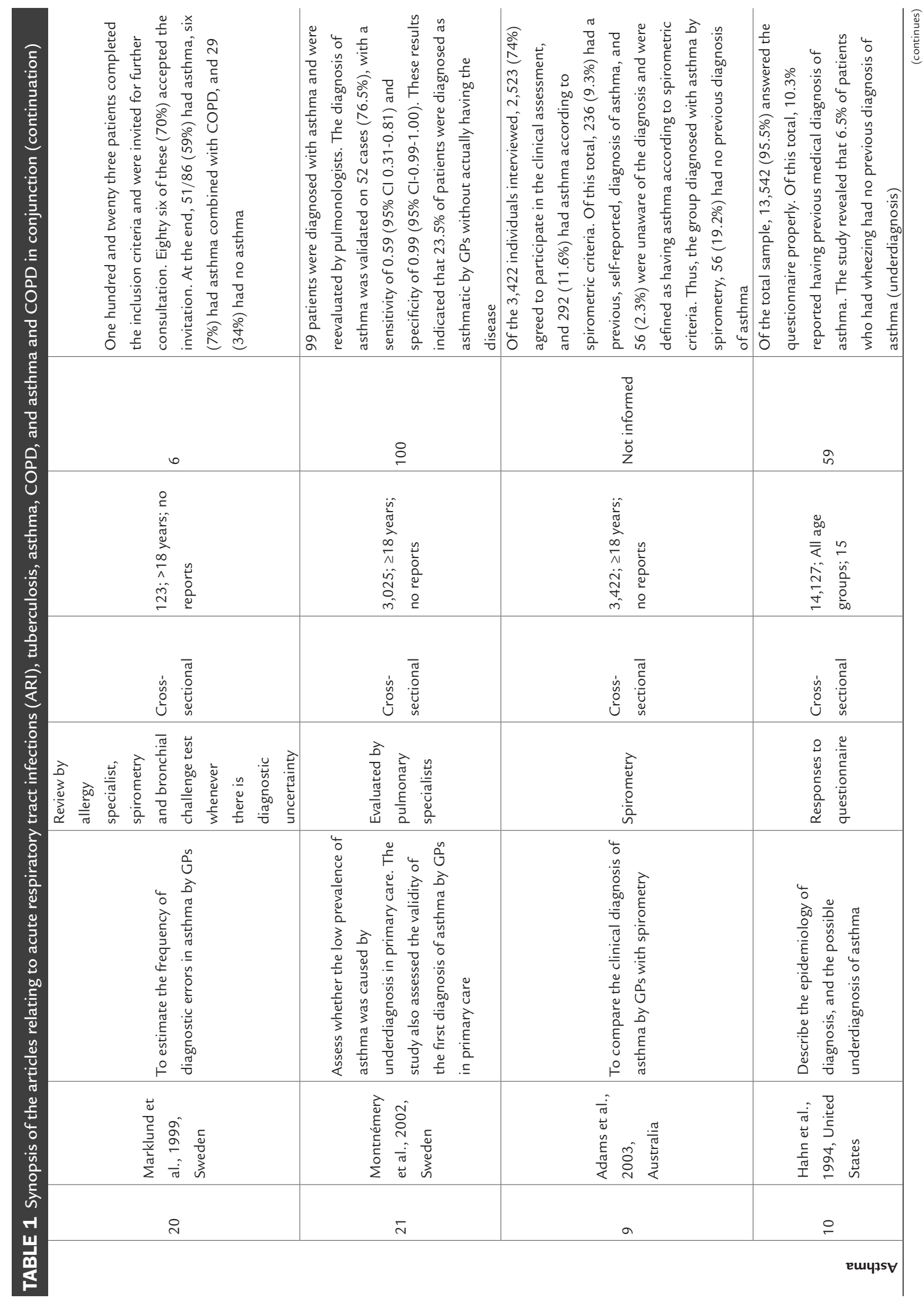




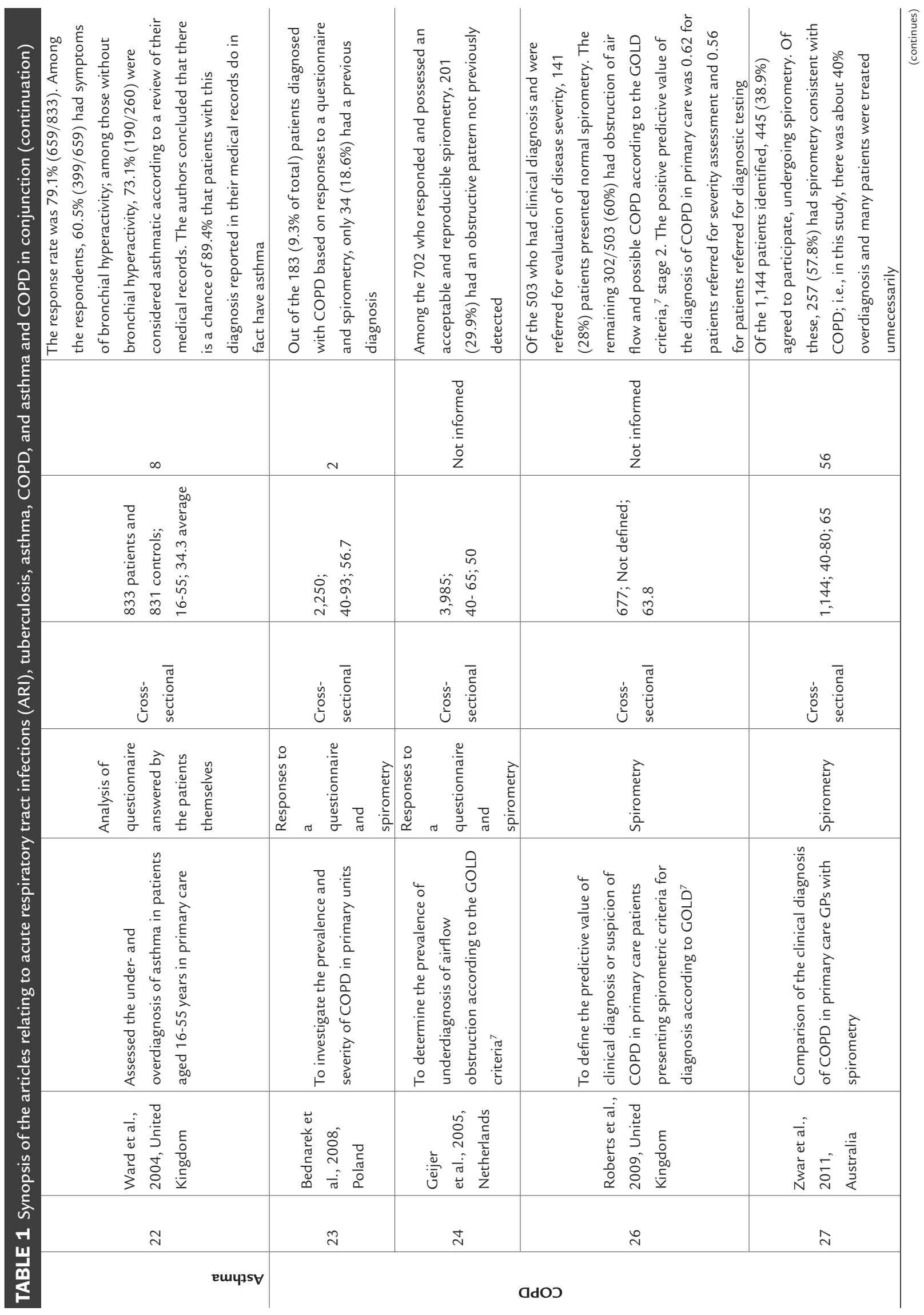




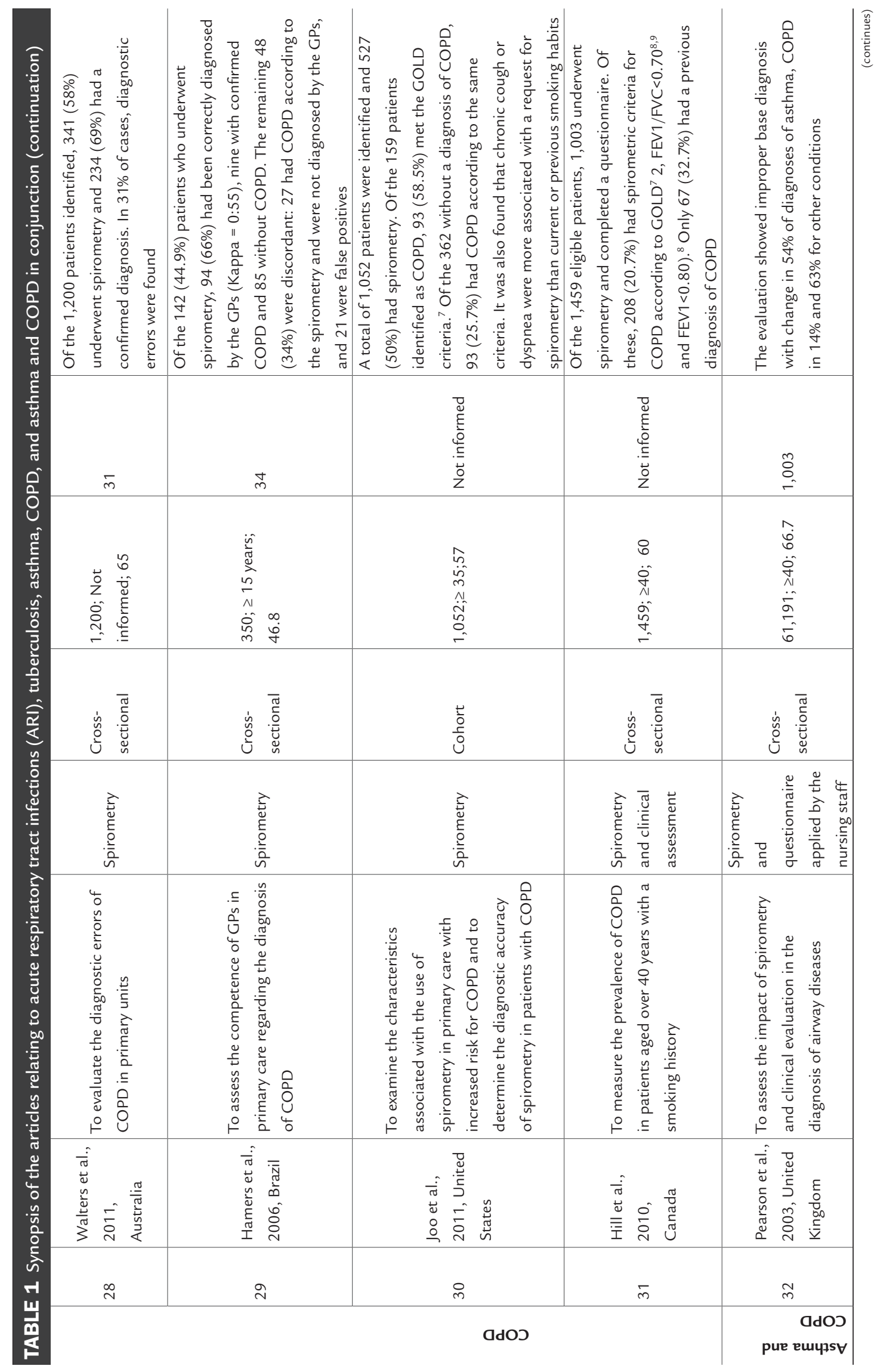




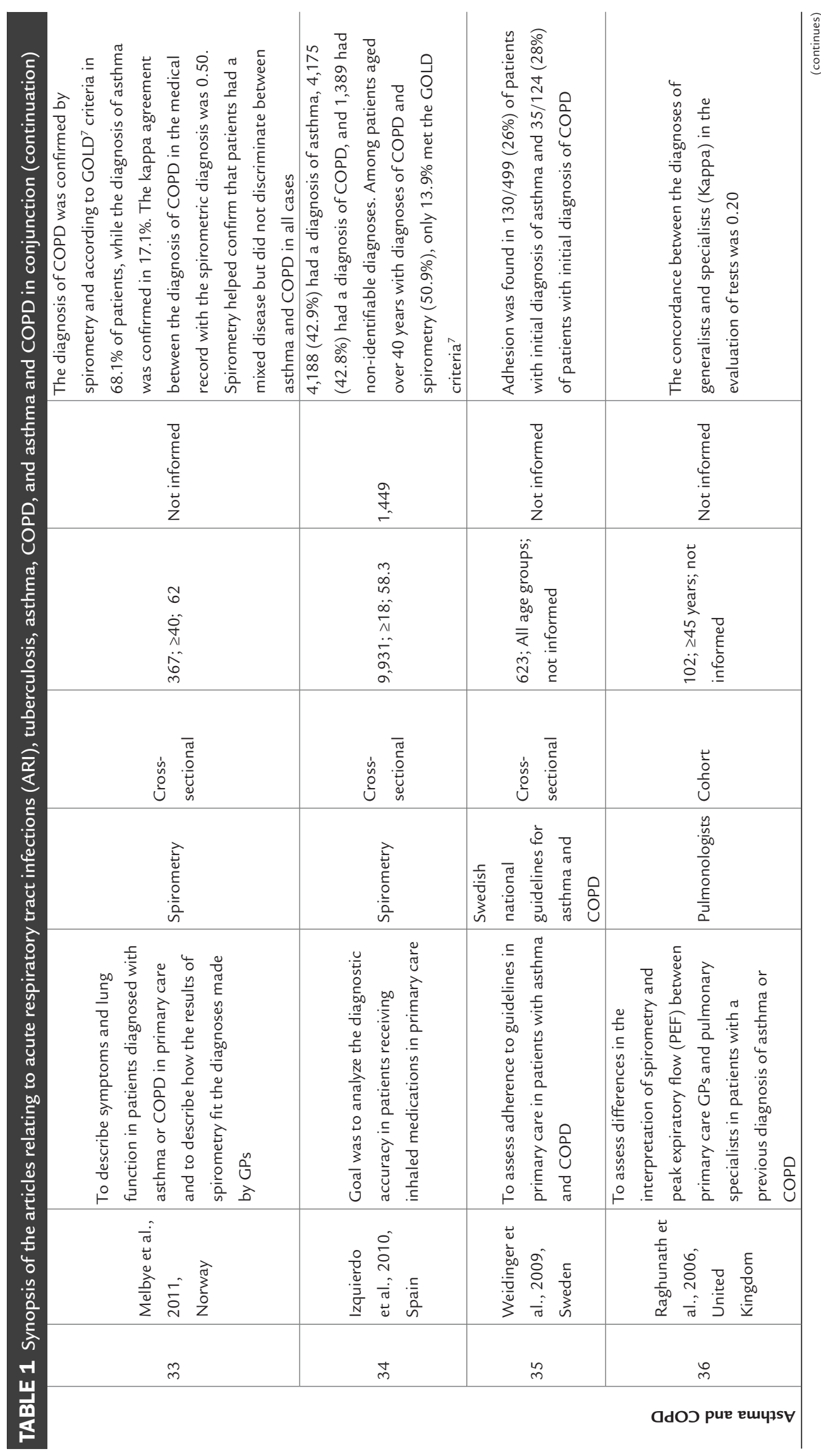




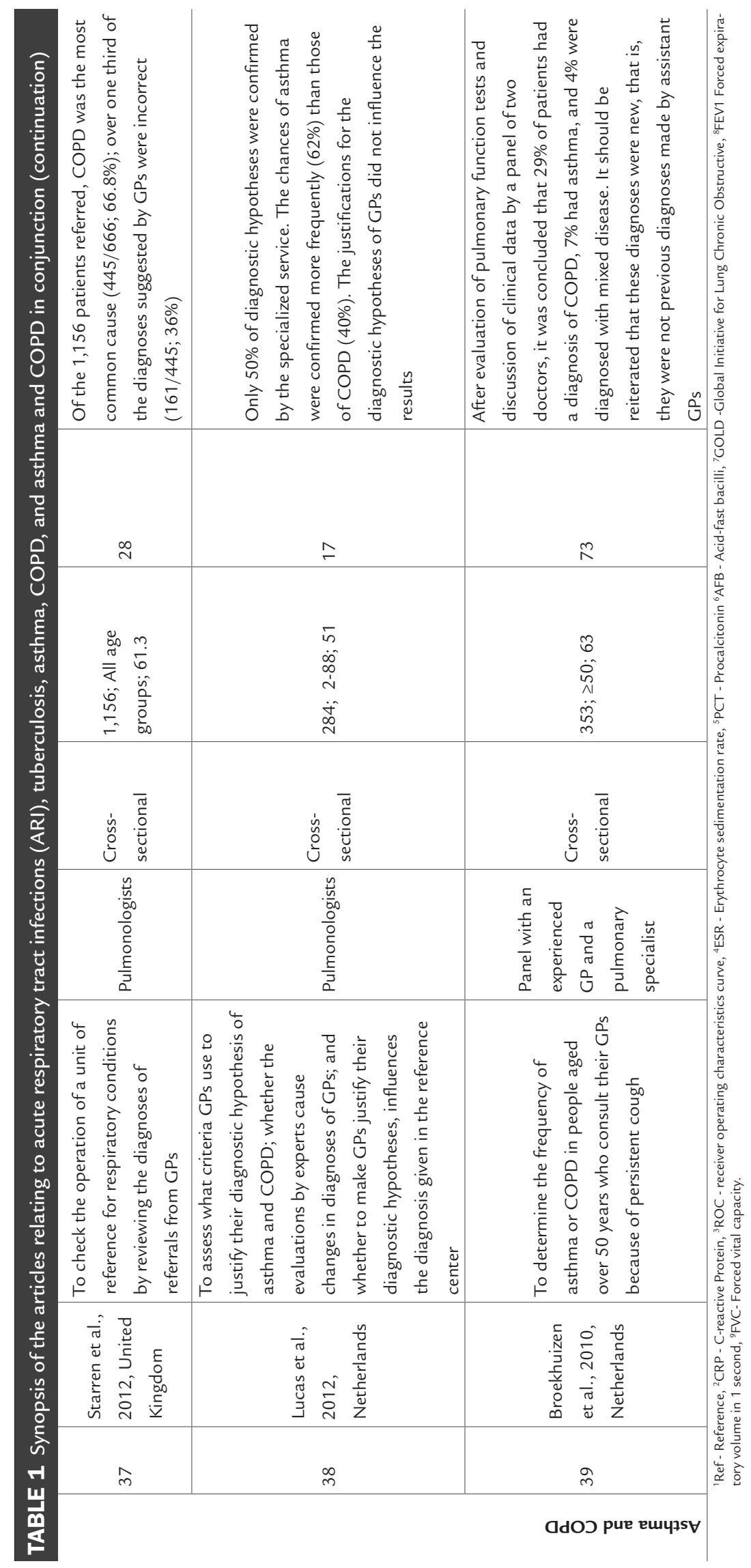




\section{Pulmonary tuberculosis}

Few studies about tuberculosis that fulfilled the inclusion criteria were encountered (Table 1). Only one reported the degree of suspicion of diagnosis or knowledge on the part of general practitioners and specialists, though this was not the main focus of the article and not directly assessed, ${ }^{16}$ while the other studies only assessed the knowledge or degree of suspicion of tuberculosis by general practitioners. ${ }^{17-19}$

\section{Asthma}

In the case of asthma, only two studies evaluated the diagnostic ability of general practitioners through a follow up evaluation by experts (Table 1). ${ }^{20,21}$

The first, conducted in Sweden in 1994 included patients aged over 18 years visiting general practitioners in selected PHC, verifying the frequency of errors in relation to asthma diagnosis by general practitioners. The patients with this diagnosis established in the medical records were invited to be examined by allergists. The diagnoses were discussed by a group that included a general practitioner and a nurse, in addition to the allergist. One hundred and twenty-three patients fulfilled the inclusion criteria and were invited to another consultation. 86 of these (70\%) accepted the invitation. At the end, 51/86 $(59 \%)$ had their asthma diagnosis confirmed, six (7\%) were diagnosed with an asthma-COPD association and 29 (34\%) did not have asthma, i.e. they were initially wrongly diagnosed. ${ }^{20}$

The second, also conducted in Sweden, investigated whether the low level of asthma diagnoses was due to underdiagnosis in PHC, as well as assessing the validity of the first asthma diagnosis by general practitioners. Over the course of three months in 1997, all patients seeking medical assistance at PHC units in the district of Lund with upper or lower respiratory tract infections, prolonged cough, allergic rhinitis, dyspnea or a first positive diagnosis of asthma were recorded $(n=3,025)$. Ninety-nine were diagnosed with asthma and reassessed by pulmonologists. The results indicated that $23.5 \%$ of patients were mistakenly considered as asthmatic by general practitioners. $^{21}$

Three other articles were evaluated: one assessed the concordance between the clinical diagnosis of asthma undertaken previously by the general practitioner with the spirometry results; ${ }^{9}$ the other two assessed the underdiagnosis of asthma and used an non-validated questionnaire as a diagnostic tool, without specialized clinical assessment or spirometry. ${ }^{10,22}$
In the five studies selected, overdiagnosis varied from $10.6^{22}$ to $34 \%^{20}$ and underdiagnosis from $6.5^{10}$ to $19.2 \%{ }^{9}$

\section{COPD}

Studies whose main focus was to assess the concordance between the diagnosis by PHC physicians and specialists were not encountered. The selected studies, which compared the diagnosis by general practitioners and spirometry results revealed mistakes in the diagnosis, characterized by both under and overdiagnosis.

In the eight studies selected ${ }^{23-31}$ overdiagnosis varied from $28^{26}$ to $40 \%^{23}$ while underdiagnosis, from $25.7^{30}$ to $81.4 \% .^{23}$

A study conducted in Brazil assessed the concordance between the diagnosis by PHC general practitioners and spirometry according to the criteria established by the GOLD initiative. 94 (66\%) of the 142 (44.9\%) of patients undergoing spirometry had concordant diagnoses with that of the general practitioners (Kappa $=0.55$ ), with 9 having a confirmed diagnoses and 85 without COPD. The remainder $(48$; $34 \%)$ was discordant: 27 had COPD according to the spirometry and were not diagnosed by the general practitioners, and 21 were false positives. In this study, the variables associated with the spirometric diagnosis of COPD were: being male, having a rural origin, the presence of dyspnea and cough, being a current smoker, being over 55 years, and exposure to smoke from wood stoves. ${ }^{29}$

\section{Asthma and COPD}

The studies encountered that evaluated asthma and COPD in conjunction are heterogeneous in relation to the methodologies employed. In the eight studies recovered, ${ }^{32-39}$ the variation in the overdiagnosis of COPD was $36^{37}$ to $86.1 \%,{ }^{34}$ while for asthma this was $38^{38}$ to $74 \%{ }^{35}$ The variation in the underdiagnosis of COPD was $14^{32}$ to $29 \%,{ }^{39}$ while for asthma this was $7^{39}$ to $54 \%{ }^{32}$ The majority used an evaluation of the database followed by reassessment of patients, with the exception of one study based on the patient's symptoms at a spontaneous visit to a primary care unit. ${ }^{39}$

For example, the Cadre study (COPD and Asthma Diagnostic/management Reassessment), conducted in the United Kingdom involved more than a thousand GPs and included over 60 thousand patients who had been treated for a respiratory condition and were reassessed using a standardized questionnaire applied by nurses, as well as spirometry. An experienced GP then evaluated the questionnaire, spirometry results and made the diagnosis. This new assessment showed incorrect diagnosis, with a 54\% 
increase in the diagnosis of asthma, $14 \%$ increase in COPD and $63 \%$ increase in other diseases. ${ }^{32}$

Broekhuizen et al..$^{39}$ assessed patients aged over 50 with persistent cough lasting more than 14 days without a previous diagnosis of asthma or COPD. After evaluating the lung function tests and discussing the clinical data in a panel formed by two physicians, it was concluded that $29 \%$ of patients had a diagnosis of COPD, $7 \%$ had asthma and $4 \%$ an overlapping condition. It should be reiterated that these diagnoses were new, that is, there was no previous diagnosis made by assistant general practitioners (Table 1). ${ }^{39}$

\section{Discussion}

This comprehensive literature review found that despite the methodological heterogeneity of the studies encountered, the accuracy of acute and chronic respiratory disease diagnoses elaborated by general practitioners in primary health care is low.

Even those approaching the conditions separately presented different methodological delineations and aspects, which hindered the interpretation and elaboration of definitive conclusions. As an example, the imprecision of the asthma diagnosis varied from 54\% underdiagnosis to $34 \%$ overdiagnosis, ${ }^{32,20}$ while for COPD there was $81 \%$ underdiagnosis up to $86.1 \%$ overdiagnosis. ${ }^{23,34}$ This heterogeneity may have occurred, at least in part, because the studies were not randomized, due to the diversification in sampling and definitions of each disease, and the variables considered in the populations analyzed.

In relation to ARI, the use of auxiliary diagnostic exams almost always resulted in improved diagnostic accuracy and consequent decrease in the prescription of antibiotics. ${ }^{12,14}$

In relation to tuberculosis, the better results from specialists over those from general practitioners in primary care seem obvious and natural, but as it is a condition of interest to national and international public health, a better performance was expected from general practitioners. ${ }^{16}$ The studies encountered prove the low level of knowledge about tuberculosis by general practitioners working in primary care. ${ }^{18,19}$

Underdiagnosis and thus under-treatment may present a significant impact on the increased morbidity and mortality of respiratory diseases. ${ }^{40,41}$ Similarly, overdiagnosis may lead to increased costs and possible collateral effects related to unnecessary treatment.

The literature reviewed places the general practitioner as the key player in the context of mistaken diagnosis, whether through lack or excess. In both cases, the degree of lia- bility of accidents for the mistakes cannot be determined. It is also difficult to determine on what proportion it can be defined as systematic errors relating to difficulties accessing exams, or cognitive errors by general practitioners - errors owing to interpretation of signs and symptoms when the patient presents them. In other words, some authors interrogate if under diagnosis is due to the inappropriate interpretation of symptoms by the physician or the patients' failure to express their symptoms to the doctor. ${ }^{42-45}$

Another point to consider is that the slow and progressive nature of diseases such as asthma and COPD seems to lead to a decreased perception of their manifestations. Cough and reduced tolerance to exercise may be seen as normal phenomena in certain age ranges. As a result, patients do not seek general practitioners and in an eventual appointment may fail to report such symptoms to their physician. ${ }^{46}$

For around 50 years it was thought impossible for blood pressure to be measure by nurses or nursing technicians. Nowadays the importance of these professionals in official blood pressure control programs is recognized. Thus, a multi-professional strategy in the detection of high prevalence diseases should be implemented as opposed to focusing solely on experts, a common approach at present. ${ }^{46}$ For example, the incorporation of simple questions in the routine of health professionals, such as "Do you smoke? Do you want to stop smoking?", as part of a program could significantly increase the diagnosis of COPD and the effectiveness of programs for smoking cessation.

The common sense that the context of PHC is less complex than those with medium to high complexity seems incorrect. PHC has the most extensive clinical practice and is where interventions of high complexity should be undertaken, such as those relating to changes in behavior and lifestyles in relation to health, including stopping smoking, adopting healthy eating behaviors and physical activity, among others. The secondary and tertiary levels of care include practices with higher technological density, but not necessarily higher complexity. This distorted view of complexity, whether singular or systematic, leads politicians, managers, health professionals and the population as a whole, to overvalue the practices that are carried out at the secondary and tertiary levels of health care and, consequently, to a trivialization of PHC. ${ }^{47}$

In the cases of the most prevalent diseases and those of major interest in the management of public health, it is expected that PHC physicians should obtain high detection rates, or at least higher levels of sensitivity, considering the fact that they provide front line medical atten- 
tion, where the lack of a medical diagnosis will result in increased morbidity or the occurrence of acute and chronic complications. Specialists have a supporting role in the diagnosis and monitoring of the more complex cases. The detection process should be primarily the responsibility of primary care, which presupposes adequate training of GPs and the implementation of a horizontal care program including the provision of medication and supplementary exams to diagnostics so that respiratory diseases can be identified and treated at an early stage.

This review includes some limitations which should be discussed. Some studies about ARI only compared prescriptions for antibiotics and did not verify the quality and accuracy of the diagnosis..$^{11,12,14}$ Other works assessed accuracy as a secondary outcome. ${ }^{15}$ Methodological differences within the same group may have compromised these results, at least in part. Various differences can be highlighted, since the stage of inclusion criteria: database or spontaneous demand reviews, age, history of smoking, through to definition of the COPD diagnosis, with some using the GOLD 1 (FEV1/FVC <70) criteria, others GOLD 2 (FEV1/FVC < 70 and FEV1 <80\%), while in others the criteria were not clearly defined. Another limitation that can be cited is the extraction of data by a single researcher, which may have affected the reproducibility of the results.

\section{Conclusion}

The results prove, in a general manner, that there are diagnostic errors and that the level of knowledge of respiratory diseases by general practitioners in various countries is lower than desired. To better understand the reality of healthcare in PHC, further studies with methodologies better defined regarding inclusion criteria and assessment tools, should be conducted. Their results could support the adoption of consistent policies for improving healthcare as a whole.

\section{Resumo}

Precisão diagnóstica de doenças respiratórias em unidades primárias de saúde.

As doenças respiratórias acometem $15 \%$ da população do planeta e respondem por $1 / 5$ dos óbitos no mundo. Espera-se que a atenção primária à saúde (APS), primeira instância da assistência médica, solucione até $85 \%$ dos problemas de saúde em geral. Pouco se sabe a respeito da habilidade de médicos generalistas da APS em relação ao diagnóstico das doenças respiratórias. Esta revisão refere-se à habilidade diagnóstica de médicos ge- neralistas que atuam na APS em relação às doenças respiratórias mais prevalentes, como doenças respiratórias agudas (IRA), tuberculose, asma e doença pulmonar obstrutiva crônica (DPOC). Dentre 3.913 artigos, 30 foram selecionados após aplicação dos critérios de inclusão e exclusão. Ficou demonstrada a carência de dados consistentes sobre a acurácia dos diagnósticos de doenças respiratórias elaborados por generalistas. Em relação à asma e à DPOC, os estudos demonstram erros diagnósticos que levam ao sobrediagnóstico ou ao subdiagnóstico, dependendo da metodologia usada. A imprecisão do diagnóstico de asma variou de $54 \%$ de subdiagnóstico a $34 \%$ de sobrediagnóstico; para DPOC, houve variação de $81 \%$ de subdiagnóstico a $86,1 \%$ de sobrediagnóstico; para IRA, verificou-se que a inclusão de exame complementar de auxílio diagnóstico melhora sua acurácia. Os estudos demonstram um baixo nível de conhecimento sobre tuberculose por parte dos generalistas. De acordo com esta revisão, a APS, na figura do médico generalista, necessita aprimorar sua capacidade de diagnóstico e o manejo desse grupo de pacientes, que constitui uma de suas principais demandas.

Palavras-chave: doenças respiratórias; atenção primária à saúde; diagnóstico; médicos de atenção primária; revisão.

\section{References}

1. Ottmani S, Scherpbier R, Chaulet P. Respiratory care in primary care services. A survey in 9 countries. Geneve: WHO; 2004. Document WHO/HTM/TB/n. 333.

2. The global burden of disease: 2004 update. WHO Library Cataloguing-inPublication Data. [cited 2012 dec 10]. Available from: http://www.who.int/ healthinfo/global_burden_disease/GBD_report_2004update_full.pdf?ua=1.

3. The top 10 causes of death Fact sheet $\mathrm{N}^{\circ} 310$. Updated June 2011. [cited 2012 dec 10]. Available from: http://www.who.int/mediacentre/factsheets/ fs310/en/.

4. World health statistics 2008. WHO Library Cataloguing-in-Publication Data. [cited 2012 dec 10]. Available from: http://www.who.int/whosis/ whostat/EN_WHS08_Full.pdf.

5. World Health Statistics 2008. WHO Library Cataloguing-in-Publication. [cited 2012 dec 10]. Available from: http://www.who.int/respiratory/copd/ World_Health_Statistics_2008/.

6. World Health Organization. Asthma. Media Centre. Fact sheet $N^{\circ} 307$. Updated May 2011. [cited 2013 mar 15]. Available from: http://www.who. int/mediacentre/factsheets/fs307/en/index.html.

7. Bousquet J, Khaltaev N, editors. Global surveillance, prevention and control of chronic respiratory diseases. A comprehensive approach. [cited $2012 \mathrm{dec}$ 10]. Available from: http://www.who.int/gard/publications/GARD\%20 Book\%202007.pdf.

8. Nascimento OA, Camelier A, Rosa FW, Menezes AMB, Pérez-Padilla R, Jardim JR, Latin American Project for the Investigation of Obstructive Lung Disease (PLATINO) Group. Chronic obstructive pulmonary disease is underdiagnosed and undertreated in São Paulo (Brazil). Results of the PLATINO Study. Braz J Med Biol Res. 2007;40:887-95.

9. Adams R, Wilson D, Appleton S, Taylor A, Dal Grande E, Chittleborough C, et al. Underdiagnosed asthma in South Australia. Thorax. 2003;58:846-50.

10. Hahn DL, Beasley JW and the Wisconsin Research Network (WReN) Asthma Prevalence Study Group. Diagnosed and possible undiagnosed asthma: A Wisconsin Research Network (WReN) Study. J Fam Pract. 1994;38:373-9. 
11. Hopstaken RM, Muris JW, Knottnerus JA, Kester AD, Rinkens PE, Dinant GJ. Contributions of symptoms, signs, erythrocyte sedimentation rate, and C-reactive protein to a diagnosis of pneumonia in acute lower respiratory tract infection. Br J Gen Pract. 2003;53(490):358-64.

12. Briel M, Schuetz P, Mueller B, Young J, Schild U, Nusbaumer C, Périat P, et al. Procalcitonin-guided antibiotic use $v$ s a standard approach for acute respiratory tract infections in primary care. Arch Intern Med. 2008;1681:2000-7.

13. Gulich MS, Matschiner A, Glück R, Zeitler HP. Improving diagnostic accuracy of bacterial pharyngitis by near patient measurement of C-reactive protein (CRP).Br J Gen Pract. 1999;49(439):119-21.

14. Bjerrum L, Gahrn-Hansen B, Munck AP. C-reactive protein measurement in general practice may lead to lower antibiotic prescribing for sinusitis. $\mathrm{Br}$ J Gen Pract. 2004;54(506):659-62.

15. Capper R, Canter RJ. Is there agreement among general practitioners, paediatricians and otolaryngologists about the management of children with recurrent tonsillitis? Clin Otolaryngol Allied Sci. 2001;26:371-8.

16. Cirit M, Orman A, Unlü M. Physicians approach to the diagnosis and treatment of tuberculosis in Afyon, Turkey. Int J Tuberc Lung Dis. 2003;7:243-7.

17. Al-Maniri AA, Al-Rawas OA, Al-Ajmi F, De Costa A, Eriksson B, Diwan VK. Tuberculosis suspicion and knowledge among private and public general practitioners: Questionnaire Based Study in Oman. BMC Public Health. 2008;26:177.

18. Hong YP, Kwon DW, Kim SJ, Chang SC, Kang MK, Lee EP, et al. Survey of knowledge, attitudes and practices for tuberculosis among general practitioners. Tuber Lung Dis. 1995;76:431-5.

19. Singla N, Sharma PP, Singla R, Jain RC. Survey of knowledge, attitudes and practices for tuberculosis among general practitioners in Delhi, India. Int J Tuberc Lung Dis. 1998;2:384-9.

20. Marklund B, Tunsater A, Bengtsson C. How often is the diagnosis bronchial asthma correct? Fam Pract. 1999;16:112-6.

21. Montnémery P, Hansson L, Lanke J, Lindholm L-H, Nyberg P, Löfdahl C-G, et al. Accuracy of a first diagnosis of asthma in primary health care. Fam Pract. 2002;19:365-8.

22. Ward DG, Halpin DM, Seamark DA. How accurate is a diagnosis of asthma in a general practice database? A review of patients' notes and questionnairereported symptoms. Br J Gen Pract. 2004;54:753-8.

23. Bednarek M, MaciejewskiJ, Wozniak M, Kuca P, Zielinski J. Prevalence, severity and underdiagnosis of COPD in the primary care setting. Thorax. 2008;63:402-7.

24. Geijer RM, Sachs AP, Hoes AW, Salomé PL, Lammers JW, Verheij TJ. Prevalence of undetected persistent airflow obstruction in male smokers 40-65 years old. Fam Pract. 2005;22:485-9.

25. Global iniciative for chonic obstrutive lung disease - COPD. Global strategy for diagnosis, manangement, and prevention of chronic obstructive pulmonary disease (Revised 2011). [cited $2012 \mathrm{dec} 12$ ]. Available from:http:www.golddpoc.com.br.

26. Roberts CM, Abedi MKA, Barry JS, Williams E, Quantrill SJ. Predictive value of primary care made clinical diagnosis of chronic obstructive pulmonary disease (COPD) with secondary care specialist diagnosis based on spirometry performed in a lung function laboratory. Prim Health Care Res Dev. 2009;10:49 AM 53.

27. Zwar NA, Marks GB, Hermiz O, Middleton S, Comino EJ, Hasan I, et al. Predictors of accuracy of diagnosis of chronic obstructive pulmonary disease in general practice. Med J Aust. 2011;195:168-71.

28. Walters JA, Walters EH, Nelson M, Robinson A, Scott J, Turner P, et al. Factors associated with misdiagnosis of COPD in primary care. Prim Care Respir J. 2011;20:396-402.
29. Hamers R, Bontemps S, van den Akker M, Souza R, Penaforte J, Chavannes N. Chronic obstructive pulmonary disease in Brazilian primary care: diagnostic competence and case-finding. Prim Care Respir J. 2006;15:299306.

30. Joo MJ, Au DH, Fitzgibbon ML, McKell J, Lee TA. Determinants of spirometry use and accuracy of COPD diagnosis in primary care. J Gen Intern Med. 2011;26:1272-7.

31. Hill K, Goldstein RS, Guyatt GH, Blouin M, Tan WC, Davis LL, et al. Prevalence and underdiagnosis of chronic obstructive pulmonary disease among patients at risk in primary care. CMAJ. 2010;182:673-8.

32. Pearson M, Ayres J, Sarno M, Massey D, Price D. Diagnosis of airway obstruction in primary care in the UK: the CADRE (COPD and Asthma Diagnostic/management REassessment) programme 1997-2001. Int J Chron Obsruct Pulmon Dis. 2006;1:435-43.

33. Melbye H, Drivenes E, Dalbak L, Leinan T, Hoegh-Henrichsen S, Ostrem A. Asthma, chronic obstructive pulmonary disease, or both? Diagnostic labeling and spirometry in primary care patients aged 40 years or more. Int J Chron Obstruct Pulmon Dis. 2011;6:597-603.

34. Izquierdo JL, Martín A, Lucas P, Moro J, Almonacid C, Paravisini A. Misdiagnosis of patients receiving inhaled therapies in primary care. Int J Chron Obstruct Pulmon Dis. 2010;5:241-9.

35. Weidinger P, Nilsson JL, Lindblad U. Adherence to diagnostic guidelines and quality indicators in asthma and COPD in Swedish primary care. Pharmacoepidemiol Drug Saf. 2009;18:393-400.

36. Raghunath A, Innes A, Norfolk L, Hannant M, Greene T, Greenstone M, et al. Difficulties in the interpretation of lung function tests in the diagnosis of asthma and chronic obstructive pulmonary disease. J Asthma. 2006;43:657-60.

37. Starren ES, Roberts NJ, Tahir M, OByrne L, Haffenden R, Patel IS, et al. A centralised respiratory diagnostic service for primary care: a 4-year audit. Prim Care Respir J. 2012;21:180-6.

38. Lucas AE, Smeenk FJ, Smeele IJ, van Schayck OP. Diagnostic accuracy of primary care asthma/COPD working hypotheses, a real life study. Respir Med. 2012;106:1158-63.

39. Broekhuizen B, Sachs A, Hoes A, Moons K,Van Den Berg J, Dalinghaus W, et al. Undetected chronic obstructive pulmonary disease and asthma in people over 50 years with persistent cough. Br J Gen Pract. 2010;60(576):48994.

40. Fletcher C, Peto R, Tinker C. The natural history of chronic airflow obstruction. BMJ. 1977;1:1645-8.

41. Speight AN, Lee DA, Hey EN. Underdiagnosis and undertreatment of asthma in childhood. BMJ. 1983;286:1253-6.

42. Van Schayck CP, Chavannes NH. Detection of asthma and chronic obstructive pulmonary disease in primary care. Eur Respir J Suppl. 2003;39:16s-22s.

43. Levy M. Delay in diagnosing asthma. Is the nature of general practice to blame? J Royal Coll Gen Pract. 1986;36:52-3.

44. Kendrick AH, Hoggs CMB, Whitfield MJ, Laszlo G. Accuracy of perception of severity of asthma patients treated in general practice. BMJ. 1993;307:422-4.

45. Bijl-Hofland ID, Cloosterman SGM, Folgering HThM, Akkermans RP, van Schayck CP. Relation of the perception of airway obstruction to the severity of asthma. Thorax. 1999;54:5-19.

46. Van Schayck CP, Van der Heijden FMMA, Van den Boom G, Tirimanna PRS, Van Herwaarden CLA. Underdiagnosis of asthma: is the doctor or the patient to blame? The DIMCA project. Thorax. 2000;55:562-5.

47. Mendes EV. As redes de atenção à saúde. Brasília (DF): Organização PanAmericana da Saúde; 2011. p.311-320. 